\title{
ESCOLA DE GENTE FEIA
}

\section{SCHOOL OF UGLY PEOPLE}

\section{ESCUELA DE GENTE FEA}

\section{Steferson Zanoni Roseiro ${ }^{1}$, Janete Magalhães Carvalho ${ }^{2}$}

\section{RESUMO}

Este artigo objetiva discutir algumas relações entre o corpo e as feiuras, procurando avaliar os abalos que um corpo feio provoca nos modelos de apreensão da subjetividade construídos prioritariamente com base nos referenciais da representação e da identidade. Parte de uma cena comum de escola para problematizar alguns possíveis limites entre as feiuras e as produções de modos de vida. Propõe, a partir do aporte de autores alinhados à filosofia da diferença, algumas possibilidades de subversão suscitadas pelo corpo feio para uma política de subjetivação que afirme uma diferença radical. Há, conforme aposta o texto, escolas de gente feia que fazem de seus corpos marcos nas transformações afetivas tecidas nas escolas. O corpo feio cria, vorazmente, insultos à lógica Capital.

PALAVRAS-CHAVE: Escola. Corpo feio. Feiuras. Resistência. Devir.

\section{ABSTRACT}

This essay aims to discuss some relations between body and ugliness, trying to evaluate the changes that the ugly body provokes on the subjectivities apprehension models constituted majorly on references of representation and identity. It starts from an usual school scene to problematize some possible limits between ugliness and the way to produce life. Using contributions of authors allied to the philosophy of difference, it proposes some possibilities of subversion raised by the ugly body for a subjectivation policy that affirms a radical difference. There are, as it is said, schools for ugly people that uses their bodies as marks to affective transformations sewed in school. The ugly body insults the Capital logic voraciously.

KEYWORDS: School. Ugly body. Ugliness. Resistance. Becoming.

\section{RESUMEN}

Este ensayo tiene como objetivo discutir algunas relaciones entre el cuerpo y la fealdad, tratando de evaluar los cambios que el cuerpo feo provoca en los modelos de aprehensión de subjetividades constituidos principalmente en referencias de representación e identidad. Se parte de una escena escolar habitual para problematizar algunos posibles límites entre la fealdad y la forma de producir vida. Utilizando contribuciones de autores aliados a la filosofía de la diferencia, propone algunas posibilidades de subversión planteadas por el cuerpo feo para una política de subjetivación que afirme una diferencia radical. Hay, como se dice, escuelas para personas feas que usan sus cuerpos como marcas para las transformaciones afectivas cosidas en la escuela. El cuerpo feo insulta la lógica del Capital con voracidad.

PALAVRAS-CLAVE: Escuela. Cuerpo feo. Fealdad. Resistencia. Devenir.

\footnotetext{
${ }^{1}$ Doutorando em Educação - Universidade Federal do Espírito Santo. Vitória, ES - Brasil. Professor da Rede de Ensino do Município de Cariacica, ES - Brasil. E-mail: dinno sauro@hotmail.com

${ }^{2}$ Doutora em Educação - Universidade Federal do Rio de Janeiro (UFRJ). Rio de Janeiro, RJ - Brasil. Professora do Programa de Pós-Graduação em Educação - Universidade Federal do Espírito Santo (UFES). Vitória, ES Brasil. E-mail: janetemc@terra.com.br
}

Submetido em: 14/12/2019 - Aceito em: 14/07/2020

(C) ETD-Educação Temática Digital Campinas, SP $\quad$ v.23 n.3 $\quad$ p. 776-792 jul./set. 2021




\section{1 [escola de gente feia1]}

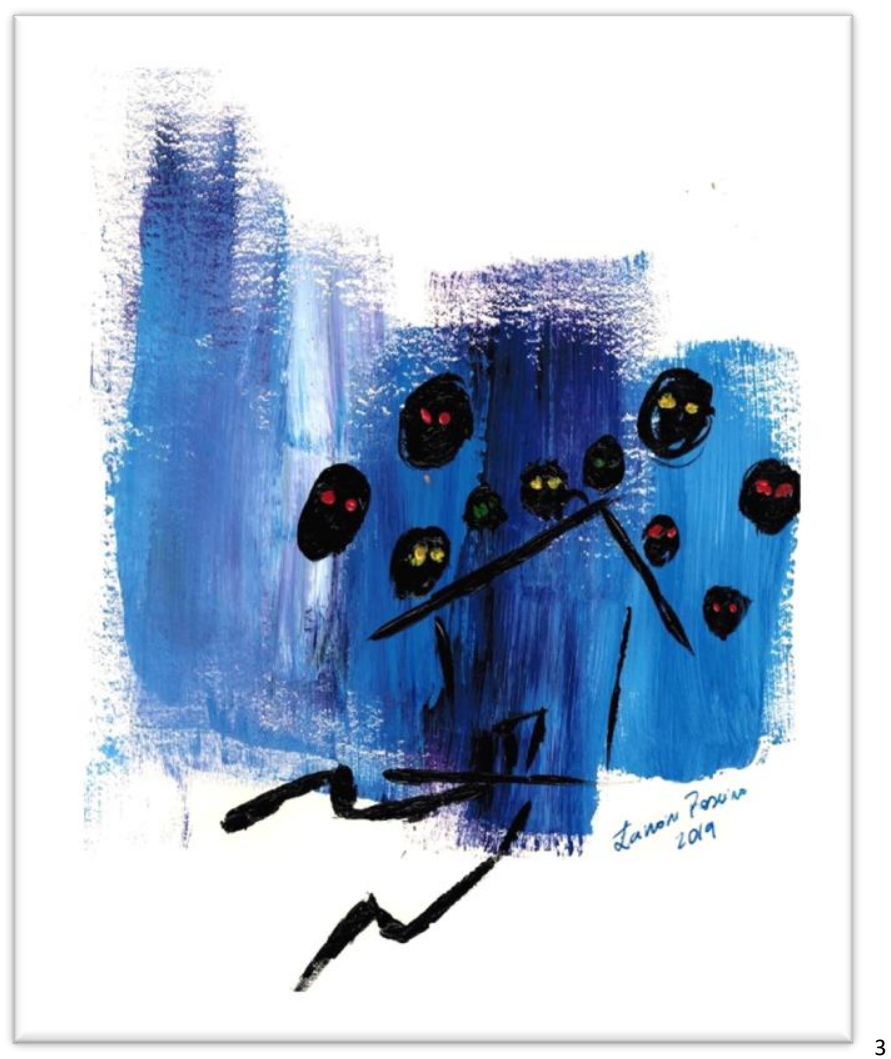

Figura1 - Escola de gente feia (acrílica)

Fonte: Os autores.

A escola até que é bonitinha. Padrão de construção sem vida, de prédio sem estilo, de cores insossas, mas, ainda assim, bonitinha, cuidadinha, limpinha. O entorno? Maravilhoso. Céu aberto, nenhum prédio. Apenas a escola. Tem um grande portão vermelho numa rua e um portão encardido em outra, tem uma quadra coberta, tem uma biblioteca grande e vazia, tem segundo andar e fim. Os porteiros são máquinas-de-olhar-de-cara-feia para o bando de crianças que entram ali com os pés tudo sujo de lama. Uma vez teve até um caso em que uma aluna, toda enlameada, foi mandada embora porque iria sujar demais a escola. O caso foi abafado, é claro, e hoje contam que aquilo foi lorota de adolescente para matar aula. Fora isso, não tem mais nada. Não tem laboratório de nada, embora existam alguns cacarecos de computador lá que não funcionam já há alguns anos; não tem horta nem jardim, nem como

\footnotetext{
${ }^{3} \mathrm{O}$ artigo apresenta duas pinturas feitas em acrílica que tem como propósito pôr a leitura em indagação. Não foram tecidos nenhum comentário ou discussão em torno delas, visto que apostamos na lógica de que uma imagem, por si só, produz os discursos a sua disposição com os quais se articula.
}

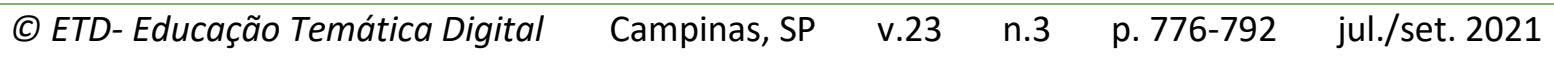


fazer, porque toda a área da escola foi coberta de concreto em suas variações; não tem corredores coloridos; não tem nem mesmo pátio aberto, porque o único lugar com céu acima das cabeças é a área próxima ao portão de saída e fica bem fechada essa área. Tudo naquela escola contribuir a favor da boa ordem da vizinhança escolar e, justamente por colaborar tanto, insurge vorazmente contra a ordenança.

Todavia, sabe o que a escola tem de sobra?

Barulho. Feiuras. Vulgaridade. Agitação. Vida.

Eis, justamente, a causa dessa história. Ali, naquela escola, é impossível entrar sem se defrontar com ataques insultuosos à ordem regulatória e às tentativas embelezantes de produção de vida regrada. Basta entrar para se deparar com crianças gritando, adolescentes urrando, professoras e professores fofocando, cozinheiras brigando, serventes rindo, porteiros cantando, famílias batendo boca... Nada ali é muito digno de uma escola modelo. Nenhum aluno naquela escola jamais seria reconhecido na televisão ou nos jornais como alunos-modelo. Nem mesmo seus professores! Não tem como entrar naquela escola, em qualquer momento do dia ou da vida, e não se deparar com alguma orquestra desarmônica. Expressões sombrias, zombeteiras, risonhas, debochadas espiam os corredores a todo o momento.

E, se nos aprazemos com a infinitude da vida, não há lugar melhor para estarmos que uma escola de gente feia.

Na escola, a cacofonia é tanta, que, para desavisados, a escola é uma baderna sem fim. Vira e volta, um professor "novo" entra numa escola e sai de lá, pouco tempo depois, convicto de que escola não é lugar de gente. Num desses episódios - aquela escola ficou famosa pelo número sem fim de desistências de potenciais professores -, uma professora, descabelada, entrou na sala dos professores pedindo arrego.

- Aquilo não é humano, não!

Alguns professores trocaram olhares entre si e, não tão discretamente, sorriram.

- Sétimo A?

- Sétimo A - respondeu a coordenadora, também dando vazão ao sorriso.

A professora continuou sua marcha.

- Eu não consigo dar aula para eles. Eles não querem que eu dê aula - ela falava rapidamente - Não que eu achasse que fosse ser um sonho dar aula aqui... mas eu esperava, ao menos, que alguém fosse querer aprender algo... uns dez! Uns cinco... DOIS, PELO MENOS

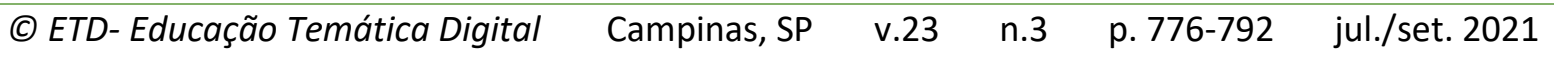


DOIS! - Em dado ponto, a professora já quase vociferava - Tudo o que eu consegui foi que um deles ameaçasse dar um soco no outro...

- Carlos e Enderson...

- E que uma aluna me chamasse na mesa dela para começar a me dar dicas... DE APARÊNCIA!

- Idril...

A cena, já recorrente para alguns dos professores ali reunidos, durou mais uns 20 minutos. A coordenadora, paciente, ouviu a história toda e pontuou, de modo bem eficaz, a saída daquela professora da escola:

- Menina, você esperava o quê? - a voz dela era bem calma, e, na verdade, até consoladora - Já olhou ao redor por aqui? Esses meninos aprendem a viver escola com Malhação e com filmes. Para eles, escola é vadiação, putaria, arquibancada e salão de beleza. E nem tô dizendo por maldade não... Olhe ao redor! Minha querida, isso daqui é escola de gente feia... crianças que vêm para bagunçar e fazer o inferno aqui, meninas que acham que vão ganhar algum concurso de beleza se passarem um quilo de maquiagem por dia; meninos que acham que bater laje é fazer academia... sou professora aqui há muitos anos, adoro essa escola, mas que só tem gente feia nesse lugar, só tem gente feia. Até os professores desse lugar são uma desgraça aos olhos ou à boa moral. Acha que eu tô aqui há tanto tempo por quê?

No dia seguinte, a professora não apareceu mais. Ninguém soube dizer se era por ter aversão a gente feia, indisciplinada e pobre ou se era por medo de se tornar, também ela, tudo isso. A maior parte dos professores que estavam lá jura, de pés juntos, que é a segunda causa. Uma professora alega ter visto que ela não estava estarrecida ouvindo a coordenadora falar. Na versão dessa professora, a professora-em-potencial-já-em-declínio estava era se olhando no espelho atrás da coordenadora.

A professora, aparentemente, travestiu-se de modo impotente e estéril. Deveras, a professora saiu correndo por ter visto rugas já se formando ou qualquer coisa do tipo.

- Nem todo mundo admite sua gostosura, né? - brincou a coordenadora por um bom tempo com as colegas - Eu me dou superbém com a minha, obrigada.

- Você se dá até bem demais, Ismeli - alguns respondiam.

É. Decididamente, há vida pulsando numa escola de gente feia.

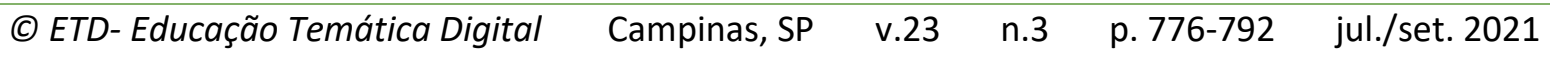




\section{2 [insultar nas feiuras]}

A afirmação de escola de gente feia, antes de implicar valores somente estéticos (pessoas gordas ou magras demais, dentuças, esquisitas, fedorentas ou quaisquer outros atributos que escapolem minimamente aos perfis de beleza traçados costumeiramente), diz de escolas que não se limitam a tentar controlar os insultos da feiura. Logicamente, não dizemos com isso não haver nenhuma maquinação capitalística - largos investimentos histórico-socioeconômico-culturais na produção dos corpos ideais - ou sequer que, dentro desses espaços, a vida não encontra empecilhos para a ampliação de sua potência (DELEUZE; GUATTARI, 2012). Não é questão de apontar a escola como um deleite, na qual tudo ocorreria às mil maravilhas, sem entraves nem desafios próprios.

Não, a questão é mais se reconhecer como espaço de luta, pois as escolas nunca são pontos de passividade.

O transbordamento de um corpo feio e estranho, visto que foge de um padrão de normalidade cultural, social e pedagogicamente aceito, ultrapassa o conteúdo representado e está para além de sua origem e de sua causa. O corpo feio é, ao mesmo tempo, absolutamente transparente e totalmente opaco.

Ao exibir a sua "deformidade", a sua "anormalidade" oferece ao olhar a sua aberração para que todos a vejam. Uma professora entra em sua primeira aula na escola de gente feia e, logo de cara, é impelida a algo que ainda desconhece. Não sabe como reagir diante do contato nada harmonioso com as forças de vida em polvorosa de uma sala de aula. Seja na ameaça explícita de uma violência física - que poderia ou não realmente ocorrer -, seja no modo quase amigável de um corpo feio se aproximar e ensinar à professora seus truques de fealdade, essas escolas exigem da vida nada menos que sua força desejante. Manifesta-se, portanto, como um corpo social que difere do corpo considerado normal na medida em que, fugindo dos padrões, revela o oculto, algo de disforme, de visceral, de "interior", uma espécie de obscenidade a-orgânica.

Tal obscenidade ele não apenas a exibe, mas também a desdobra, virando a pele pelo avesso e desfraldando-a, sem se preocupar com o olhar do outro, para fasciná-lo. Se a beleza está nos olhos de quem vê, a feiura está na pele de quem vive em explosões de intensidade.

Para Gil (2006), o que fascina é que o interior se corporifique e não seja realmente um corpo, porque é sua alma abortada que exibe: seu corpo é o reverso de um corpo com alma.

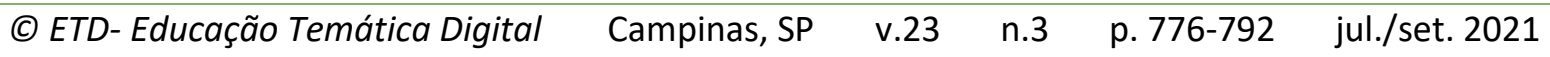


Nesses termos, estamos na presença de um corpo não codificado, que prolifera num processo de absorção dos signos e assim se transforma em uma espécie de signo delirante, parasitando todos os outros signos da linguagem. Trata-se, portanto, da irrupção no espaço social de um corpo assignificante que, devorando os signos, amedronta e provoca angústia em nosso ser cultural-social.

A escola nunca é ponto de passividades.

Carvalho e Roseiro (2015), nesse sentido, provocam o pensar de quanto os corpos estudantis invadem os dispositivos de controle. Na escrita dos autores, enxerga-se uma vida fugidia, e não apenas uma vida nua, com vivacidade o suficiente para fazer os operários do controle disfarçarem sorrisos e fazerem vista grossa às interrupções maquínicas operadas pelos alunos e alunas - alvo dos poderosos espaços estriados. Isto é, ainda que Ihes peçam sossego, que lhes exijam uma vida alunada, também professoras e professores se dão conta da própria maquinaria que os abarca e os consome.

Por mais controladora que se deseje, a vida dá conta de escapar justamente pela baderna, precisamente em pequenos atos insurrectos.

Ferdinand Deligny (2018) e seus vagabundos transeuntes fazem-nos encontrar essa mesma premissa: o diretor do centro, ao invés de preferir professores bem-formados, instruídos nas mais finas artes, optava pelos operários, pelos jovens que nada tinham a oferecer, pelos indigentes refugiados de guerra. No prefácio escrito em 1970 para o livro do Deligny, Émile Copfermann (2018, p. 133) anunciava:

Nossos educadores não eram educadores de verdade. Fugidos dos esgotos do gueto de Varsóvia, judeus alemães e intelectuais sem identidade, como nós esperavam o retorno à normalidade para se misturar com os outros. Quanto a nós, gostávamos muito deles. Não nos ensinavam nada ou bem pouco.

Há algo que apenas o contato visceral com a vida pode efetivamente suscitar. Para infortúnio de uns, os corpos demasiado controlados tendem a evitar expor suas vísceras, a fazer de sua vida uma exposição de suas feiuras. Nas escolas, topamos sempre com alunos que disputam por boas notas. Vira e volta, algum novo programa ou concurso são lançados pelas Secretarias de Educação para premiar os bons alunos, professores, gestores etc. E, quando premiados, pedem-Ihes suas histórias de sucesso. A fealdade - as desconquistas, as brincadeiras, a vitalidade de tudo aquilo que não segue o ritmo propriamente capitalístico da concentração e produção da vida regrada - é deixada de lado. 
A questão, como Deleuze e Guattari (2012) lembram, não é nos livrarmos das organelas - professoras e professores demasiado diplomados bem-intencionados -, mas do organismo, dessa máquina que envia códigos às máquinas menores, exigindo-lhes cortes, fluxos. Não seja possível nem sequer desejável uma vida em que tudo foge loucamente, em que nenhum tipo de organização se cria, em que não há mínima possibilidade de conversação entre os corpos e as forças. É preciso fazer a paranoia controladora cacarejar anunciado seus ovos, mas, ao mesmo tempo, dar-lhe o golpe de não ter nenhum ovo sob suas penas.

E, por isso mesmo, a própria escola, vendo-se girar sem muito controle, abre mão em parte - dos controles que se esperam dela.

A campanha eleitoral dos presidenciáveis em 2018 evidenciou, de modo peculiar, a força política da escola como nenhum outro presidente fez antes. A escola - e a educação em geral - sempre foi bem "visada" por nossos governantes. Todavia, foi durante esse processo que o obscurantismo se voltou, sem piedade, para a escola, envolvendo a todos os corpos transeuntes daquele espaço. Ao final de 28 de outubro, data do segundo turno, uma deputada do PSL (Partido Social Liberal) incitou alunos de todo o país a gravar as aulas de seus professores porque aquele seria o momento de provar a doutrinação realizada nas escolas. "Amanhã é o dia em que os professores e doutrinadores estarão inconformados e revoltados", dizia ela em seu convite (ESTADÃO, 2018). Mais recentemente, a "[...] ministra dos Direitos Humanos, Damares Alves, afirmou, em Belo Horizonte, que o governo federal vai criar um canal para que pais de alunos possam reclamar de professores", alegando ser necessário o combate ao comunismo das docências que agem "contra a moral, a religião e a ética da família" (VEJA, 2019).

Todo esse processo persecutório e de criminalização dos docentes busca engendrar um novo princípio da realidade em que, envoltos pelo medo do constrangimento, da judicialização, inclusive da demissão, resultaria na impossibilidade de garantir a sua sobrevivência, consolidando um estado de passividade diante das problemáticas sociais e das opressões mais corriqueiras.

$\mathrm{Na}$ lógica atual, todos os corpos precisam ser normalizados e regularizados seguindo fluxos aceitáveis à lógica capitalística. Pouco importa se os fluxos são conservadores fundamentalistas, neoliberais "simpáticos" ou humanistas - importa apenas estar de acordo com a regra da manutenção infinita da vida, de sua submissão às mudanças de fluxo e da competição exasperada.

Tornamo-nos o alvo de estratégias que precisam desmoralizar nossos corpos para funcionarem. As feiuras, em muitos momentos, são alvo de ataques irracionais estranhamente bem arquitetadas. A estratégia história mais corriqueira foi sempre a de se investir na monstruosidade dos corpos demasiado perigosos à ordem para que possam se

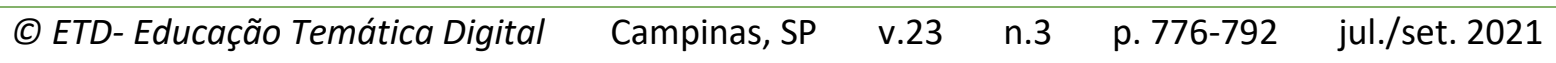


unir, d'algum modo, contra todos nós, sem criar grandes desordens. A diferença é que, dessa vez, foram as escolas públicas que se tornaram o alvo dos ataques públicos; foram os professores e alunos das instituições públicas de ensino que passaram a ocupar os holofotes da ameaça à sociedade. ${ }^{4}$ Aos poucos, nós mesmos aprendemos a temer e a desconfiar uns dos outros.

A ameaça comunista lança-nos, como Eduardo Galeano (2013) lembra, a uma era de procura da própria sombra. Desconfiamos de todos! Todos fomos enfeados em graus infinitos.

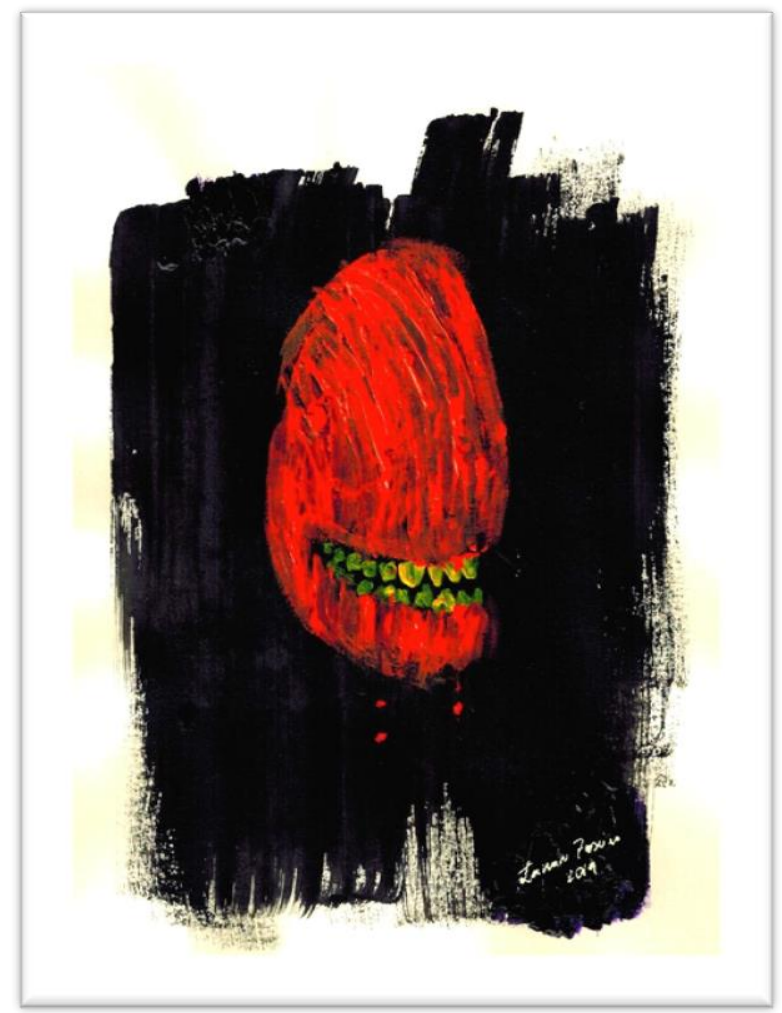

Figura2 - A ameaça comunista (acrílica)

Fonte: Os autores.

\footnotetext{
${ }^{4}$ Cabe destacar, entretanto, que os professores têm sido atacados há muitas gerações de governo e o governo petista não foi uma exceção a isso. Seja com a redução do quadro de professores permanentes nas redes de ensino, com os cortes nos investimentos ou com a criação de empecilhos à progressão no plano de carreira, a educação pública sofre ataques estratégicos sempre que desponta nela a força insurrecional. Os ataques à educação foram sempre evidentes a quem atua nesse lugar, todavia, no governo de Jair Messias Bolsonaro, foi uma das primeiras vezes em que vimos o próprio discurso político nos atacar e tentar tornar-nos inimigos da sociedade.
}

(C) ETD- Educação Temática Digital $\quad$ Campinas, SP $\quad$ v.23 $\quad$ n.3 $\quad$ p.776-792 jul./set. 2021


$E$, se aprendemos com as vivências nas escolas de gente feia, não nos envergonhamos dessa nossa repentina fealdade. Ao contrário, optamos por expô-la felizes.

Uma vez que nos tornamos ameaças, damo-nos conta de nossas aberturas às feiuras.

Rimos descaradamente dos tolos que acreditam terem doutrinado alguém em salas de aula. A direita conservadora ainda não entendeu que há sempre resistências. Não doutrinamos nossas alunas e alunos, e, todavia, algo é inegável: os afetos produzidos dentro de uma escola carregam a força da vida.

Não fomos capazes de criar um exército comunista. Rimos dessa premissa! Mas os afetos estão ali, os corpos preparados para lutar. Nessa cena, ganhamos todos um par extra de mãos, de abraços, de laços. Diante da ameaça tão declarada às esquerdas, lembramos de ver o marxista, o negriano, o foucaultiano, o savianista, o freiriano e todos os outros como aliados, como corpos tão insultuosos quanto os nossos. "Ninguém solta a mão de ninguém" - lema que se multiplicou após o aumento de ataques fascistas aos corpos menos normativos - virou um princípio autocrítico, um lembrete de outros corpos que se colocam conosco em batalha.

Uma escola de gente feia requer esse mínimo cuidado autocrítico.

Em escolas reais, professoras e professores entram em contato com as feiuras continuamente. Professoras rigorosas encontram alunos insultuosos e nem sempre o confronto é injusto. Há, em muitos casos, uma mútua alimentação da vontade de viver. Ismeli, coordenadora, comumente é associada à imagem do controle, ao poder quase militar atuante em escolas. Espera-se de uma coordenadora que ela possa acalmar uma guerra. E, todavia, quando diante da feiura de um corpo, não se comporta como uma figura militar, antes, avivase com fulgor e responde às implicâncias, vê a vida transitar como quem quer lembrar-se jovem novamente.

No contato com as feiuras, o corpo, muitas vezes, aproxima-se por vontade de viver mais que por vontade de competir. Se Nancy Etcoff (1999) evidencia que a beleza impele o instinto de sobrevivência a partir da perspectiva darwinista - isto é, demonstrando que a beleza corpórea esteve sempre atrelada à manutenção da espécie humana, garantindo-lhe maior destaque na competição pelas condições básicas de sobrevivência -, pensamos, por outro lado, que a feiura se associa à vida por multiplicação das possibilidades de sobrevivência. Maurizio Lazzarato (2011) sugere que a competição é o motor do Capital; Deleuze e Guattari (2011), não muito longe disso, lembram que a maquinaria capitalística se alimenta de nossa vitalidade. Por sua vez, entretanto, a feiura foge a essa lógica. Antes de competir, ela chama os próprios corpos a se multiplicarem. Ou, como sugeriria Massumi

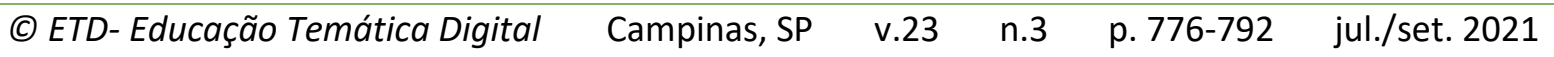


(2017), a feiura é, talvez, o traço de uma multiplicidade de vida já derivada, de um corpo que ampliou a própria noção de corpo.

Talvez, retornando à pequena cena que abre este texto, víssemos naquela professoraque-foge justamente a reação de quem não sabe como lidar com as feiuras. Nos espaços onde a vida se multiplica de modo demasiado ramificado, os corpos diferentes não são expelidos, antes são atraídos e colocados em conversação com os outros. Paul Preciado (2018) contanos alegremente que, por baixo da aparente regularidade de um convento, ele/ela conseguia encantar quem lhe apetecesse mesmo dada a sua fealdade.

A feiura invade as relações normatizadas em demasia para, no lugar, exigir articulação com a vida em sua potência. Não se trata, como o senso comum espera, de causar repulsa. Pouco se teme ou se tem asco da feiura. Antes, ela atrai por implicar uma variação afirmativa da vida.

Antes de uma destruição indiferente do outro, nessa escola de gente feia "está latente a necessidade de construção de uma vida comum" (CARVALHO, 2009, p. 146), isto é, um comum que "seja entendido como proliferação de atividades criativas, relações ou formas associativas diferentes" (ibidem, p. 162).

Se Eduardo Galeano (2013) evoca um mundo avesso para fazerem sentido as atrocidades anunciadas nos jornais do fim do século XX, evocar um plano de imanência na qual o comum se faça o desejo primeiro é nada menos que apostar nos corpos como força de vida. Se a escola do mundo avesso "nos ensina a padecer a realidade ao invés de transformála, a esquecer o passado ao invés de escutá-lo e a aceitar o futuro ao invés de imaginá-lo" (GALEANO, 2013, p. 8), na escola de gente feia, fazemos tudo errado apenas por implicância.

Talvez, se nos aproximássemos mais de Ismeli, do Anael, da Josélia ou de quaisquer outras figuras temidas por uma lógica de controle, acabássemos percebendo certas politizações nem sempre com tomadas à direita e aos conservadorismos. Por vezes, essas professoras pegam no pé de suas turmas para que eles tomem dianteira nos movimentos estudantis, nas manifestações, na afirmação e explicação de suas decisões.

Ela pode ser velha e, decididamente, pode ser brava. Sua braveza, entretanto, talvez não seja sinal de quem segue ordens militarmente. Quiçá vemos nela a braveza de quem está acostumada a lutar pela sobrevivência. Afinal, anos numa mesma escola que afirma, desavergonhadamente, ser uma escola de gente feia não é um compromisso fajuto.

Ali, como diria Judith Butler (2014), os corpos são produzidos a partir de resquícios de guerras, de imagens de uma precariedade que parece ser a única alternativa. Permanecer em uma escola e afirmar a potência da feiura, mesmo quando o quadro diante de si tende a

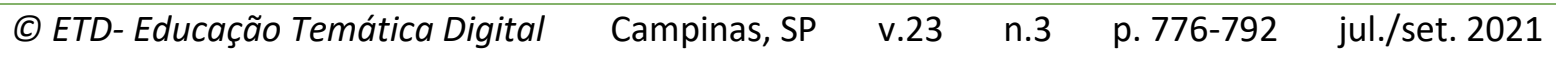


adoecer, é, sem dúvida, posicionar-se politicamente a favor da produção de uma vida muito mais ativa que qualquer estratégia política pode sonhar.

As docências não apenas devem carregar traços geneticamente feios. Devem existir feiuras imanentes a elas em seu andar, seu olhar, seus afetos. No mínimo, é preciso partilhar aí de alguns conluios.

Os graus de feiura de um corpo variam infinitamente.

Talvez seja justamente por esse excesso de atividade afetiva, por esse excesso de vida é que as lógicas embelezantes, por serem destruidoras de mundos, fazem cafetinagem com os corpos. Precisam seduzir-nos, precisam que fiquemos sob o feitiço da seguridade e, ao mesmo tempo, sob o torpor da paranoia (ROLNIK, 2018).

Querem que desconfiemos de tudo e de todos, para que, de algum modo, vejamos nesse outro - o belo corpo - a estabilidade de uma vida justa. Eis o motivo de, em plena era das tentativas de controle total de nossas capacidades cognitivas, a beleza, a aparência e o autocuidado estético emergirem até mesmo em documentos reguladores das práticas educacionais ${ }^{5}$.

Essa perspectiva quase cômica de pensar o corpo não nos diz de forças intoleráveis ou de um regime estético reinante. É claro, segundo salientam Denise Bernuzzi Sant'Anna (2014), Georges Vigarello (2006) e a própria Virginie Despentes (2016), vivemos, sim, uma época em que todas as imagens que circulam na sociedade nos intimam à vida, de modo a pagar com nosso próprio embelezamento. "Só é feio quem quer", dizia uma propaganda analisada por Denise Sant'Anna (2014). Ou, ainda, só é feio quem é muito burro! Afinal, há um barateamento escancarado dos produtos cosméticos, há um enriquecimento estético dos produtos diários da vida, há um alargamento amplo das redes médico-estéticas (VIGARELLO, 2006; SANT'ANNA, 2014). A moça bela serve, conforme Despentes viu no filme King Kong, como a armadilha da feiura, a armadilha da monstruosidade.

Ainda assim, antes de vermos as políticas intoleráveis da beleza cafetina, vemos o medo delas.

Os dispositivos de governança temem as escolas por sermos esse espaço em que os mais infinitos corpos entram em contato uns com os outros. Na escola entram o pobre, o preto, a gorda, a lésbica, a macumbeira, o viado, o bi, o ateu, a travesti, a menina certinha, o vagabundo, a professora entusiástica, a professora secular... tudo é imagem de escola, todos

\footnotetext{
${ }^{5}$ No documento curricular homologado em 2017, Base Nacional Comum Curricular, a educação passa a ser também impulsionada por valores estéticos corporais, de autocuidado e de higiene, em muito retomando questões vivenciadas no período de eugenização da educação da década de 1930 (VIDAL, 2000).
}

(C) ETD-Educação Temática Digital Campinas, SP $\quad$ v.23 n.3 $\quad$ p. 776-792 jul./set. 2021


os corpos compõem esse plano de imanência. E, se não nos restarem a sede competitiva e uma fastuosa paixão por nós, vemos e veremos noutros corpos pontos de contágio, forças insultuosas.

Querem-nos competindo uns com os outros, querem que temamos os outros justamente porque, do contrário, aprenderíamos a compartilhar redes de comum, aprenderíamos a explorar afetos para além do estritamente necessário.

Porque a feiura, decerto, faz isso.

Se Roseiro, Rodrigues e Alvim (2018) diziam que a beleza se torna um grande agenciamento maquínico de servidão imensurável, dizemos, antes, haver uma infinidade de forças que deslocam os corpos em direção ao incomparável. Embelezar-se implica, sob a lógica do controle, saltar aos olhos do outro de modo a lhe amortecer os juízos.

Insultar, então, o Capital é trabalho dos corpos.

Ao contrário do que dizia o Foucault da disciplina, não somos corpos dóceis. Como Davis Alvim (2018) vocifera em um auditório, as filosofias da educação raramente dão conta de pensar a educação porque, enfaticamente, elas tendem a ignorar os clamores estudantis, tendem a ignorar os corpos e os afetos dos estudantes.

O feio - anômalo, outsider, estranho - tem muitas funções: ele não apenas tangencia cada multiplicidade, mas também constitui a condição da aliança necessária ao devir, às mudanças, levando cada vez mais longe, na linha de fuga, as passagens de multiplicidades ou transformações dos corpos e dos afetos (PEIXOTO JR., 2010).

A desterritorialização presente nessa dimensão implica a instauração de um agenciamento, uma circulação de afetos impessoais, uma corrente alternativa, a qual, atuando como uma máquina de guerra que anula diferentes tentativas de reterritorialização, tumultua os projetos significantes das estratégias de controle. Trata-se, assim, da instauração de uma individuação impessoal, a partir da qual a escola feia, no seu devir, põe em questão o conceito de sujeito e a primazia do simbólico no campo da produção de subjetividades.

Segundo Brian Massumi (1992), existiria no devir uma tensão entre dois modos de desejo, um de ordem molar e o outro de ordem molecular, o primeiro remetendo à identidade e o segundo à diferença. Se, com certa frequência, o ponto de partida dos devires diz respeito a uma situação molar, em cujos confins algumas alternativas tendem a se apresentar como escolhas entre seres molares, "uma molaridade, diferente daquela normalmente atribuída ao corpo que foge da coerção, sugere a si mesma como uma imagem de "liberdade" (MASSUMI, 1992, p. 94). Assim, ainda que a escolha pelo devir esteja assentada em termos molares, o processo posto em ação não é, ele próprio, molar, pois envolve vetor

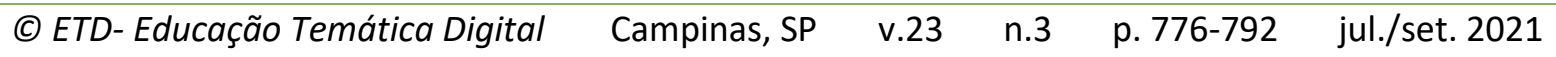


de transformação que permite traçar uma trajetória mutante que arrasta as normalidades molares para o reino do monstruoso e do molecular.

As feiuras nunca estão só. Ismeli as vê espreitarem-se para todos os lados e por uma boa razão: elas criam relações imprevistas, desmoronam certas estéticas e inventam novas liberdades.

Nos últimos anos, somos lembrados de escolas com muito mais vida que o controle gostaria de admitir. E a tudo fazem para tornar o corpo insultuoso das escolas um corpo de alto grau de periculosidade social. Em 2013, nas Jornadas de Junho, os corpos escolares tornaram-se vândalos; em 2016, nas Ocupações, fomos preguiçosos e vândalos novamente; em 2018, tornamo-nos doutrinadores; agora, em 2020, somos um risco viral em época pandêmica. Curiosamente, não se trata de dizer que não se deve estudar, mas de dizer que, quando próximos corpórea e afetivamente, nos tornamos um risco ao biológico da vida. ${ }^{6}$ Nos termos de Galeano (2013), há uma democratização do delito. Curiosamente, o delito cai, sempre, sobre o pobre, o politizado, o feio, o desocupado.

Em muitos períodos da história da arte, o bom era o belo, e o feio era ruim. No mundo artístico, isso vem sendo quebrado em frangalhos desde a industrialização do mundo (ECO, 2007). A história da feiura, à sombra de Umberto Eco, é hoje a da transformação ínfima da vida contra os próprios limites. A feiura borra os cantos de todas as imagens que fazemos das coisas, justamente por localizar-se, com mais força, nas bordas.

Apesar de nossa insistência até aqui em delegar ao feio um lugar não estético, é também possível falar da feiura ligada aos valores estéticos. Todavia, corpos indisciplinados irrevogavelmente caem também no lugar de uma feiura moral-patológica. A delinquência democratizada cai, quase majoritariamente, sobre o corpo feio. Não mais acreditamos na lógica que imperava com Oscar Wilde em Dorian Gray: que a feiura da alma deixa no corpo traços de sua brutalidade, porém, a qualquer sinal estético de feiura, desconfiamos piamente. $\mathrm{Na}$ coordenação, um dos discursos mais rasteiros é a alegação da beleza que, por algum motivo, deveria acalmar alunas e alunos. "Minha linda" e "meu lindo" viram tentativas de desarmar a postura combativa no interior das escolas.

A feiura insultuosa é real, mas não fechada aos afetos, ao sensível.

Aí, talvez pudesse jazer nosso olhar enviesado para as lógicas curriculares.

\footnotetext{
${ }^{6}$ É evidente que, com isso, não dizemos serem desnecessárias as precauções tomadas para evitar que se espalhe o novo coronavírus. Todavia, é curioso observar que, em instituições privadas, o isolamento social foi automaticamente prosseguido de aulas digitais. Logo após, alguns órgãos públicos seguiram a deixa das instituições privadas e também estabeleceram alianças com softwares e plataformas digitais, para que as aulas fossem realizadas. Uma vez mais, valoriza-se o cognitivo em detrimento das relações afetivas.
}

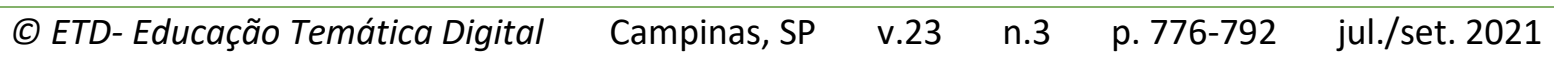


As feiuras, sempre presentes na escola, não se aquiescem. Latente em afetos, e comungando com outros corpos, o corpo das feiuras transita por entre a escola sempre pronto insultar as lógicas reguladoras abertamente admiradas. A simpática Idril, que logo assusta a professora com seu inesperado convite à beleza às avessas, nada faz além de oferecer ao corpo já perfeitamente enquadrado a possibilidade de transitar entre óticas. DáIhe, minimamente, uma possibilidade de fuga, ainda que breve. Convida-o a sair de um lugar já confortável.

Nos jogos curriculares, as tentativas de banimento vindas de professoras e professores não são poucas. Todavia, ainda assim, o corpo das feiuras transita indecoroso com todos os olhares rancorosos que lhe deitam. As docências podem responder-Ihe entrecortadamente. Ismeli, vez por outra, dá às feiuras uma resposta sempre tão indevida quanto a própria feiura.

Justamente esses pequenos cortes é que a fazem viva.

A coordenação não é apenas lugar de poder.

Nos jogos curriculares, a vida das feiuras evoca também a feiura para os jogos de controle. $E$, mediante essas trocas, o controle pode também fraquejar, colocar-se em pausa e descobrir-se aberto à comunalidade dos corpos.

\section{3 [escola de gente feia 2]}

Nas escolas de gente feia, há sempre uma Idril, uma Ismeli, um Anael, um Aristeves, um João, uma Carolina. Essas são escolas reais, escolas que criam lutas continuamente. Lutas por vida, por passagem de afetos. E, ao mesmo tempo, elas só existem quando as evocamos em conversas com os outros.

O corpo feio provoca pequenas rupturas em suas passagens. Por vezes, irrita um professor aqui, outro acolá. Frequentemente, esses corpos se desentendem com a gestão de uma escola, mas, ao invés de sangue, aumentam-se os afetos entre eles e ao redor. Cada vez que um corpo feio invade uma sala, o risco de uma derrota curricular para as docências é grande e, ainda que isso aconteça, feiuras e docências bicam-se, entrosam-se, dão continuidade às lógicas curriculares não controladoras. Ali é que as bordas vão verdadeiramente ser borradas.

Assim, produzimos conhecimentos a partir de nossos corpos, pois corpos estranhos fogem da estética da beleza, do padrão cultural europeu e da prática da perfeição. As feiuras vivem em fuga às pedagogias da perfeição que não dialogam com os corpos reais (FARIA; BESSA-OLIVEIRA, 2010). Transitam, tão livres quanto podem, por entre as tentativas de controle e, quando conseguem, debocham livremente delas. Conforme brincam Roseiro e Carvalho (2020, p. 13): “Ante qualquer cara de asco ou desgosto, talvez fosse necessário

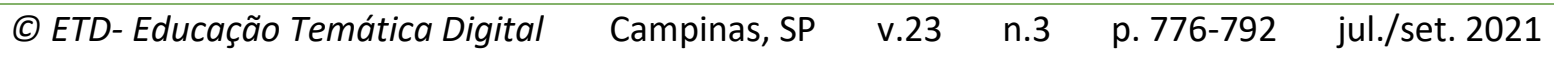


experimentar a feiura para dar-se conta do longo gozo que esses corpos produzem, das relações possíveis para além da competição e da desavença".

Ainda que cheia de problemas, uma escola de gente feia pergunta-se, continuamente, pelas vidas que têm produzido, pelas relações que seus corpos estabelecem. Ainda que os padrões sociais, econômicos e culturais atravessem continuamente seus espaços, essas escolas geram vidas inconformadas e recusam a lógica dos corpos dóceis. Brota, entre seus transeuntes, um comunismo do desejo curricular (CARVALHO, 2015) que rompe com códigos relativamente estáveis.

Traça-se, entre as feiuras dessas escolas, um conceito demasiado caro à filosofia da diferença: o comum, isto é, a zona de compartilhamento de afetos, ações, pensamentos, amizades, ideias, carinhos, cuidados. Quando as práticas curriculares de uma escola verdadeiramente se abrem às feiuras, criam-se zonas de comunalidade (CARVALHO, 2009), na qual o que muda é o próprio modo de um corpo se relacionar com a vida ao seu redor. Ali, no lugar de enxergar o outro como um risco à vida, enxerga-se o outro como parte da própria possibilidade de ampliar a vitalidade de seu corpo.

Ali, a lei do mais belo ou a do mais forte não perduram.

Ao viverem ativamente os corredores das escolas, os espaços de uma sala de aula, as implicâncias juvenis e os desejos aprendentes, as escolas de gente feia convocam os corpos a explodir o eu em feiuras infinitas. Quando se multiplicam em afetividades, as feiuras são um insulto às lógicas do Capital.

\section{Referências}

ALVIM, Davis Moreira. Filosofias da ocupação. In: SEMINÁRIO MÁQUINAS, GÊNEROS E SEXUALIDADES: CORPOS EM CURTO-CIRCUITO, 1., 2018. Anais... Vitória: UFES, 2018.

BUTLER, Judith. Quadros de guerra: quando a vida é passível de luto? Trad. Sérgio Lamarão e Arnaldo Marques da Cunha. Rio de Janeiro: Civilização Brasileira, 2015.

ARVALHO, Janete Magalhães. O comunismo do desejo no currículo. In: FERRAÇO, Carlos Eduardo; RANGEL, Iguatemi; CARVALHO, Janete Magalhães; NUNES, Kezia Rodrigues. (Org.). Diferentes perspectivas de currículo na atualidade. Petrópolis: DP et Alii; Nupec/Ufes, 2015.

CARVALHO, Janete Magalhães. 0 cotidiano escolar como comunidade de afetos. Petrópolis: DP et Alii; Brasília: CNPq, 2009.

CARVALHO, Janete Magalhães; ROSEIRO, Steferson Zanoni. O insulto da feiura na escola: insurreições contra o capital. Childhood \& Philosophy, Rio de Janeiro, v. 16, mar. 2020, p. 01-25.

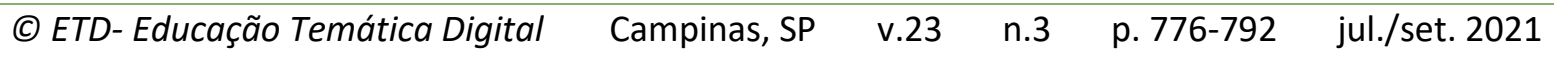


CARVALHO, Janete Magalhães; ROSEIRO, Steferson Zanoni. Vida nua, vida-criança, vidaaluno: rastros de identidade e diferença afirmando um "estado de exceção". Currículo sem Fronteiras, v. 15, n. 3, p. 599-613, set./dez. 2015.

COPFERMANN, Émile. Prefácio. In: DELIGNY, Fernand. Os vagabundos eficazes: operários, artistas, revolucionários: educadores. Tradução de Marlon Miguel. São Paulo: n-1 edições, 2018.

DELEUZE, Gilles; GUATTARI, Félix. 28 de novembro de 1947 - Como criar para si um Corpo sem Órgãos? In: DELEUZE, Gilles; GUATTARI, Félix. Mil platôs: capitalismo e esquizofrenia 2, vol. 3. Tradução de Aurélio Guerra Neto. 2. ed. São Paulo: Ed. 34, 2012.

DELEUZE, Gilles; GUATTARI, Félix. O anti-Édipo: capitalismo e esquizofrenia 1. Trad. Luiz B. L. Orlandi. 2. ed. São Paulo: Ed. 34, 2011.

DELIGNY, Fernand. Os vagabundos eficazes: operários, artistas, revolucionários: educadores. Tradução de Marlon Miguel. São Paulo: n-1 edições, 2018.

DESPENTES, Virginie. Teoria King Kong. Tradução de Márcia Bechara. São Paulo: n-1 edições, 2016.

ECO, Umberto. História da feiura. Tradução de Eliana Aguiar. Rio de Janeiro: Record, 2007.

ESTADÃO. Deputada aliada de Bolsonaro cria canal anônimo de denúncia contra professores. Por: Julia Lindner. Publicado em: 29 de out. de 2018. Disponível em: https://politica.estadao.com.br/noticias/geral,deputada-aliada-do-bolsonaro-cria-canalanonimo-de-denuncia-contra-professores-universitarios,70002571720 . Acesso em: 14 de janeiro de 2019.

ETCOFF, Nancy. A lei do mais belo. Trad. Ana Luiza Borges de Barros. Rio de Janeiro: Editora Objetiva, 1999.

FARIA, Juliano Ribeiro; BESSA-OLIVEIRA, Marcos Antônio. Meu/nosso corpo estranho, o que temos é dele/nele que somos: cultura, bios, educação. Filosofia e Educação, Campinas, v. 11, n. 1, p. 5-35, jan./abr. 2019.

GALEANO, Eduardo. De pernas pro ar: a escola do mundo ao avesso. Tradução de Sergio Faraco. Porto Alegre: L\&PM Editores, 2013.

GIL, José. Monstros. Lisboa: Relógio D’Água Editores, 2006.

LAZZARATO, Maurizio. O governo das desigualdades: crítica da insegurança neoliberal. Trad. Renato Abramowicz Santos. São Carlos: EdUFSCar, 2011.

MASSUMI, Brian. A user's guide to capitalismo and schizophrenia: deviations from Deleuze and Guattari. Cambridge: MIT Press, 1992.

MASSUMI, Brian. O que os animais nos ensinam sobre política? Trad. Francisco Trento e Fernanda Mello. São Paulo: n-1 edições, 2017.

(C) ETD-Educação Temática Digital Campinas, SP $\quad$ v.23 $\quad$ n.3 $\quad$ p.776-792 jul./set. 2021


PEIXOTO Jr., Carlos Augusto. Sobre corpos e monstros: algumas reflexões contemporâneas a partir da filosofia da diferença. Psicologia em Estudo, Maringá, v. 15, n. 1, p. 179-187, jan./mar. 2010.

PRECIADO, Paul B. Texto junkie: sexo, drogas e biopolítica na era farmacopornográfica. Trad. Maria Paula Gurgel Ribeiro. São Paulo: n-1 edições, 2018.

ROLNIK, Suely. Esferas da insurreição: notas para uma vida não cafetinada. São Paulo: n-1 edições, 2018.

ROSEIRO, Steferson Zanoni; RODRIGUES, Alexsandro; ALVIM, Davis Moreira. Estéticas da carne: insurreições curriculares do corpo feio. Revista Brasileira de Estudos da Presença, Porto Alegre, v. 8, n. 2, abr./jun. 2018, p. 277-300.

SANT'ANNA, Denise Bernuzzi de. História da beleza no Brasil. São Paulo: Contexto, 2014.

VEJA. Damares anuncia canal para denunciar professores por atos contra a família.

Publicado em 20 de nov. de 2019. Disponível em:

https://veja.abril.com.br/educacao/damares-anuncia-canal-para-denunciar-professorespor-atos-contra-a-familia/?utm source=email . Acesso em: 22 nov. $2019 \mathrm{~b}$.

VIDAL, Diana Gonçalves. Prática, experimental e científica: a formação docente na administração Anísio Teixeira da educação carioca (1931-1935). In: SMOLKA, Ana Luiza Bustamante; MENEZES, Maria Cristina. (Org.). Anísio Teixeira, 1900-2000. Provocações em educação. Campinas: Autores Associados, 2000.

VIGARELLO, Georges. História da beleza: o corpo e a arte de se embelezar, do Renascimento aos dias de hoje. Tradução de Léo Schlafman. Rio de Janeiro: Ediouro, 2006.

Revisão gramatical realizada por: Francisco Peixoto

E-mail: $\underline{\text { rancp3@yahoo.com.br }}$ 